N53

NM M I I 
SMITHSONIAN INSTITUTION LIBRARIES

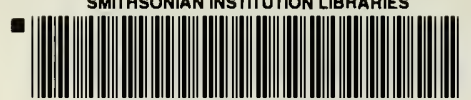

39088010702884

Hollinger Corp. pH 8.5 


\section{The Pueblo Land Problem}

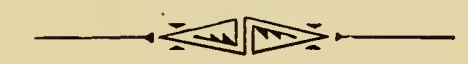

PUBLISHED AND DISTRIBUTED BY

The New Mexico Association on Indian Affairs

SANTA FE, NEW MEXICO 



\section{FOREWORD}

This Bulletin is issued by the New Mexico Association on Indian Affairs as an listorical statement of law and fact which must serve as a basis for any proposed Pueblo legislation. It is in the nature of an open letter, which we hope will elucidate the complex Pueblo land problem and unite all friends of the Indians in a co-operative effort toward constructive legislation for the Pueblos.

The policy of the Association was fully set forth in the official Blue lionk published last year in connection with its fight on the defeated Bursum Bill, in which it was stated that "Congressional action is required, but it must be action based upon fairness to both sides and not action favoring one side as against the other."

The New Mexico Association will welcome any criticism of fact or policy indicated in this outline, if such criticism is based upon supportable argument or evidence, and will be guided thereby in its recommendations for constructive legislation at the coming session of Congress.

(Signed) MARGARET McKITTRICK, Chairman.

JAMES L. SELIGMAN, Vice-Chairman.

B. J.. O. NORDFELDT, Secy.-Treas.

GUSTAVE BAUMANN,

WITTER BYNNER,

WM. P. HENDERSON,

SARA W. MCCOMB,

FRANCIS C. WILSON,

Executive Committee. 



\section{THE PUEBLO LAND PROBLEM}

I.

\section{HISTORY}

The present Pueblo land conflict is the result of seventy-five years of neglect-a neglect which the next session of Congress has the power to rectify by just legislation.

\section{The Treaty With Mexico, 1848}

To understand the situation, it is necessary to review briefly the history of the Pueblo land grants from the time when the United States, by formal treaty with Mexico, assumed possession of territory now included in New Mexico, Arizona and California. Under the Treaty of Guadaloupe Hidalgo, ratified in 1848, the United States guaranteed the protection of all civil and property rights of residents of the Mexican Republic, who, by the terms of the Treaty, were to remain under the jurisdiction of the United States. Article IX of the Treaty reads as follows:

"Mexicans who, in the territories aforesaid, shall not preserve the character of citizens of the Mexican Republic, conformably with what is stipulated in the preceding article, shall be incorporated into the Union of the United States, and be admitted at the proper time (to be judged of by the Congress of the United States) to the enjoyment of all the rights of citizens of the United States, according to the principles of the constitution; and in the meantime shall be maintained and protected in the free enjoyment of their liberty and property, and secured in the free exercise of their religion without restriction."

The subsequent confirmation by Congress of the Pueblo grants, secured under Spanish and Mexican sovereignties, did not represent a gift from Congress to the Pueblo Indians but was a specific fulfillment of this treaty obligation.

Prior. however, to the date of the Treaty of Guadaloupe Hidalgo, certain settlements of non-Indians had been made within the boundaries of the Pueblo grants, and these settlements existed by virtue of Spanish or Mexican grants, or by virtue of gift, compact or purchase from the Pueblo Indians. (Several of the larger towns within Pueblo grants, such as Taos and Bernalillo, originated from such grant, compact or purchase.)

In confirming the Pueblo grants, Congress, therefore, recognizing the existence of such valid third party rights, provided for them in the quit-claims given to the Pueblos, in the following langrage : 
"This confirmation shall only be construed as a relinquishment of all title of the United States to any of said lands, and shall not affect any adverse valid rights, should such exist."

If, at the date of confirmation of the grants to the Pueblos by the United States, provision had been made for the adjudication and settlement of these conflicting Indian and non-Indian claims, this particular feature of the present problem would have been disposed of. As it is, there exists this class of non-Indian claimants to Pueblo lands, whose title the United States could not, and can not extinguish, since these titles, like those of the Pueblo grants, are superior to American sovereignty and are guaranteed equal protection by the terms of the Treaty of Guadaloupe Hidalgo.

\section{The Crux of the Problem}

But, in addition to this class of non-Indian claimants, we have today a large body of non-Indian settlers on the Pueblo grants who hold their lands by virtue of claims originating since 1848. And the question as to how these claims were acquired represents the crux of the Pueblo land problem.

To answel this question, we must go back to the Organic Act creating the Territory of New Mexico. This act was passed by Congress in 1850 , and by its provisions all the lands within the territory, apart from Indian reservations and the public domain, were placed under territorial jurisdiction, without excluding the Pueblo grants from such jurisdiction. Consequently, due to the failure of Congress to make such exception, the Pueblo grants, not being reservations, became subject to the operation of Territorial laws, and continued so for sixty-two years.

\section{Pueblo Land Status Till 1912}

Meanwhile, the Bureau of Indian Affairs, soon after the signing of the Treaty of Hidalgo, assumed to a certain extent an administrative guardianship over the Pueblo Indians, and by course of conduct these Indians thus became wards of the government, as they have remained ever since.

As regards the land status of the Pueblo Indians, however, it was held in effect both by the territorial courts and by the United States Supreme Court, that, since the United States had not reserved any Federal jurisdiction or control over the Pueblo grants, these grants were therefore by the terms of the Organic Act subject to all territorial laws, including those of adverse possession.

In this connection it must be borne in mind that the status of the property rights of the Pueblo Indians is distinctly different from that of Indians living on Executive Order or Treaty Reservations where title is still held in trust by the United States. Against these 
Reservation Indians, as against Indians holding restricted allotments, no plea of adverse possession nor of laches can be maintained, since neither plea can be asserted against the Government. When, lowever, the Government has relinquished all title to and has no pecuniary interest in the lands of its wards, and when these lands are not, by specific legislation, retained under Federal jurisdiction, it has been decided by the United States Supreme Court that the Government has no interest which entitles it to maintain a suit brought in connection with such lands. (United States v. Waller, 243 U. S. 452.) Congress can authorize the United States to bring such suits, but in that event the United States, acting for the Indians by Congressional authorization, can in the case of their lands, assert no greater rights than the Indians themselves. When, in such suits, laches or statutes of limitation can be asserted against the titles of the Indians, they can also be urged against the Government. (Folk v. U. S. 233 Fed. 177. 192; C. C. A. Eighth Circuit.)

Such has been the decision of the courts of the United States in regard to the property rights of other tribal or individual Indians, who like the Pueblos are still technically wards of the Government but who like them have been given title in fee to their lands without restriction.

\section{Power of Congress}

As regards the Pueblo land grants, it might have been asserted that any restriction placed upon their titles would have been a violation of their rights under the Treaty of Guadalupe Hidalgo. But it was still within the Constitutional power of Congress, through appropriate legislation, to protect these grants against aggressions which. under the territorial law, might operate to their disadvantage, as in fact they did.

\section{The Joseph Case, 1877}

In 1877 the case of Tnited States v. Joseph (94 U. S. 614), brought to enforce a Federal penalty against a trespasser on the Taos Pueblo grant, the Supreme Court decided that the Pueblo Indians were not tribal Indians within the meaning and intent of federal statutes applicable to tribal Indians whose title was retained in trust by the United States, and that the claim of this settler must be tried out under territorial law. After discussing the terms by which the Pueblos hold their lands, the Court said:

"It is unnecessary to waste words to prove that this was a recognition of the title previously held by these people, and a disclaimer by the government of any right of present or future interference, except such as would be exercised in the case of any individual holding by competent and perfect title in his individual right. 
"If the defendant is on the lands of the Pueblo, without the consent of the inhabitants, he may be ejected or punished civilly, by a suit for trespass, according to the laws regulating such matters in the Territory. If he is there with their consent or license, we know of no injury which the United States suffers by his presence, nor any statute which he violates in that regard."

In other words, this decision established the fact that the Pueblo lands were under Territorial jurisdiction; and-in the absence of Congressional action - this decision became the precedent followed in all similar cases until the time of the passage of the State Enabling Act in 1910.

\section{Pueblo Land Status After 1912}

The Enabling Act required the Territory at the time it became a State (January 6,1912 ) to agree with the Government that all the land of the Pueblo Indians to which their title had not been extinguished on the date when the Territory became a State should "be and remain subject to the disposition and within the absolute jurisdiction and control of the United States." This act, by reserving jurisdiction over Pueblo lands and excluding them from State jurisdiction, automatically remored these lands from the operation of State laws and made them subject only to Federal law and control. The responsibility for protecting such lands after 1912 was thus placer squarely upon Congress. The compact required by the Enabling Aet became effective on January 6, 1912, and from that date henceforward no claim of adverse possession under State laws could be maintained against the Pueblo grants. In the State Enabling Act, Congress did what it should have done in the Organic Act creating the Territory. Subsequently, the constitutionality of the Enabling Act was upheld by the Supreme Court in the case of Sandoval v. United States, 1913, (231 U. S. 28).

\section{Non-Indian Claimants}

But between the dates of the Organic Act and Statehood-from 1850 to 1912 - the number and area of non-Indian holdings on Pueblo lands increased to an extent that has, in the case of certain Pueblos, menaced their existence by taking from them a large proportion of their arable lands, with an attendant loss of water for irrigation, upon which the cultivation of their remaining lands depends.

It must be recognized, however, that a comparatively small number of claimants to Pueblo lands whose claims originated subsequent to 1848, are of the "squatter" class. Many of the settlers hold their lands by virtue of deeds secured from the Pueblos, through direct purchase from individual Indians or community 
grants. Some of the deeds were secured by fraud on the Indians and others for an inadequate consideration, but the lands are now held for the most part by innocent purchasers for value, or by the heirs of the original grantees.

\section{Moral Responsibility}

Unfortunately, the question whether the compensation was adequate or inadequate, or whether the titles were, as in known cases, originally obtained by fraud, or whether the sale was made by an individual Indian without the consent of the Pueblo community, could not affect the situation, after that transfer had, through the lapse of time, ripened into a perfect title under territorial law. This fact emphasizes again the moral responsibility of a great and powerful nation, presumably acting as the guardian of a weak and dependent people. Not only should the Pueblo grants liave been protected against encroachments, but the United States should have defined its guardianship and should have-supervised and protected the property interests of its wards to a far greater degree than it did. In the matter of encroachments, it may be stated that, although the Pueblos as corporations under the Territorial laws (Section 2784, N. M., Code 1915, construed Lane v. Santa Rosa 249 U. S. 110) had access to the courts and could have ejected trespassers by due process of law, they were, in reality, helpless to act in their own defence, because of their ignorance of our laws and procedure. And even in the case of the United States Indian agents and attorneys who were empowered to represent the Pueblos, the law was such, prior to 1912, that they could achieve little on behalf of their clients. From the time of the first Territorial Indian agent, James C. Calhoun, appointed in 1848, until today, practically every Indian agent and attorney has reiterated a request to the Indian Office that the matter of the disputed claims be adjudicated and settled. Calhoun recommended in 1850 that a commission be appointed by Congress to establish the respective Indian and non-Indian claims. After confirmation by Congress of Pueblo grants in 1858, surveys were made establishing their boundaries, and upon these surveys the Pueblo patents were based; but practically nothing has been done by Congress from 1848 to the present day to provide adequate methods and means to settle the conflicting third-party claims, and no Congressional action prior to the Enabling Act was taken to protect the Pueblo grants as confirmed by Congress against subsequent encroachments. In the act ereating the Court of Private Land Claims (1891), Congress asserted its authority to protect Pueblo lands by limiting the jurisdiction of that Court, so that it could not confirm Spanish and Mexican claims that would "interfere with or overthrow any just and unextinguished Indian titre to any land or place"; but still no special tribunal was created by Congress to say what Pueblo titles had or had not been extinguished. 


\section{Recompense}

The conditions that have arisen resulting from this absence of Congressional action represent an injustice and a pecuniary loss to the Pueblos for which due recompense should be made. It is a moral obligation which Congress should recognize. But, owing to the human as well as legal nature of the problem now involved, the moral responsibility is not single, but double; and restitution to the Pueblos in any form that it may take must be made without injustice to the settlers on Pueblo grants, who in the majority of cases hold their lands in good faith, and who have, moreover, under Territorial law, acquired vested property rights which may not be impaired or destroyed.

What, then, is the solution of this very intricate human and legal and moral problem?

II.

\section{SOLUTION}

As an attempt towards such solution, the Bursum Pueblo Land Bill (S. 3855), defeated last winter, was shown in both the Senate and House Committee hearings to be a manifestly unfair piece of legislation, against which the public was justly aroused. It was completely one-sided in giving to the non-Indian claimants practically everything claimed, without any possibility of redress by the Pueblos or by the Government in their behalf. This bill is now dead.

\section{The Lenroot Substitute.}

The Lenroot Substitute, which was reported out of the Senate Sub-Committee, retains the Senate number of the original Bursum Bill; but, from that point on, all similarity between the two bills ends. In fact every word of the original Bursum Bill was stricken out, and even the title was amended. The Lenroot Substitute passed the Senate, but did not come to a vote in the House, owing to lack of time. The Lenroot Bill was an attempt to legislate in conformity with the facts and the law set forth in the foregoing historical survey.

\section{Compensation}

As it stands, the bill represents in principle a just and equitable solution of the conflicting land titles; but due to the nature of the Committee in which the bill originated, it could carry no appropriations for recompense to the Indians, for the arable and other lands lost to them because of the perfection of non-Indian titles against them under Territorial laws. The question of compensation was fully discussed in the Senate hearings, and it was understood that, in the event of the reporting out from this Committee of a bill de- 
voted wholly to the settling of the disputed land titles, a second bill providing a method for arriving at adequate compensatiun to the Indians would be presented through the proper Committee in the House or Senate.

It has now become clear that no compensation can be made until the extent of compensation which both the Indians and the settlers may be entitled to receive shall have been officially determined and presented to Congress.

Thus, the Commission should be authorized and directed to report to Congress the compensation which both the Indians and the settlers may be entitled to receive. No other method of arriving at a solution of this difficult feature of the situation would be satisfactory to Congress, nor could compensation be expected without the basis of the findings of such a commission on the subject.

\section{Statutes of Limitation.}

As regards the statute of limitation section of the Lenroot Substitute, it has been shown above that the non-Indian claimant who can maintain his title under the 'Territorial adverse possession statutes prior to January 6,1912 , has a vested property right which may not be impaired or destroyed. This is the principle recognized in Section 4 of the Lenroot Bill. It is possible, however, to improve this Section so that it will conform more nearly with the complete protection of vested rights in both the Indians and the settlers. For convenience' sake and to clarify this statement of conditions under Territorial laws of settlers claiming rights without color of title and those claiming rights with color of title, the discussion will be separated and treated in two paragraphs.

(a) Without Color of Title. Under a law enacted February 1 , 1858, appearing as Section 2938 of the Compiled Laws of 1897 of New Mexico, the right to recover lands entered upon without color of titlc but with claim of right was barred after ten years possession. (Prohst v. Trustess, 129 U. S. 182; Maxwell Land Grant Co. v. Dawson, 151 U. S. 586). This law was amended, so as to require adverse possession under color of title, by Chapter 63 of the Session Laws of 1899, approved March 16, 1899, and thereafter under that Section no title to real property could be gained in New Mexico without color of title. Thus, to leave undisturbed the rights which became vested by entries made under the law passed February 1, 1858, ten years prior to the amendment of that section in 1899, and at the same time to protect the Indians from the assertion of claims of less standing. the limitation without color of title but with claim of right should commence with March 16,1889 , and run continuously to the passage of the proposed bill.

(b) With Color of Title. Prior to 1912 there were two pertinent statutes, one passed. originally February 1, 1848, now appearing as Section 3364 of the Annotated Codification of 1915, and. Chapter 63 Session Laws of 1899 referred to in the preceding paragraph. 
now appearing substantially as enacted as Section 3365 of the Annotated Codification of 1915 . Under the first statute, which has been continuously in effect since its passage in 1848 , ten years possession united with color of title conferred title upon the adverse claimant, and under the second, ten years adverse possession with color of title united with the payment of taxes by the adverse claimant barred the owner from the right to recover. On January 6,1912 , the Territorial statutes of limitation applicable to real property ceased to be effective against the Pueblo Indians. Thus to leave undisturbed the rights which have vested under those statutes on January 6, 1912, and to protect the Indians from the assertion of claims of less standing, the limitations with color of title of the proposed legislation should commence on January 6 , 1902. and run continuously to the date of the passage of the Act.

It will be asked why the limitations should run continuously to the date of the passage of the bill and for the information of those to whom this question might occur, it may be stated that under the Territorial statutes mentioned which operated only to bar the right of the fee simple owner to recover, an abandonment by the claimant at any time after the statutes have run would permit the owner to re-enter the land and claim it as his own, and thus, an abandonment, if it should be proven at any time up to the passage of the bill, would permit the Indians to reclaim such land.

\section{Safeguards}

Primarily, the Jimitation section should act as a restricting safeguard upon the discretionary powers of the Commission. The commission provided for in the Jones-Teatherwood bill, submitted by friends of the Pueblos last year, had no check upon its discretionary powers, and as Senator Lenroot pointed out in the Committee hearings, Congress would never give its consent to a commission which could operate without restrictions imposed by Congress. The justice of this is evident. Congress would not be responsible for any measure which did not insure by its stated provisions protection in law and equity for its wards and for the non-Indian claimants. Any proposed legislation on the subject should include this principle of restriction upon the power of the Commission.

By the terms of the Lenroot Substitute, the Pueblo Lands Board can not approve any non-Indian claim having less standing in law and in fact than the limitations section of the bill provides. The Board is required to be unanimous upon every decision and thus a difference of opinion upon either law or fact would leave the Indian title unextinguished and subject to a final decision in the courts.

If the finding of the Commission is against the non-Indian claimant, the land is included in the report to the Attorney General as Indian land. The Attorney General is directed to bring a suit to quiet title in the Federal Court for the District of New Mexico 
on the lands in the report described as Indian lands. The nonIndian claimant therefore has his day in court to determine whether he has a just claim or not, and the usual procedure as to appeal is provided for. Where the finding of the Commission is against the Indian, the Pueblo involved has no direct appeal from the decision, but if such decision should result in taking from the Pueblo land to which it had a good and indefeasible title, the Pueblo would have its recourse, its day in court, by means of an original proceeding in the Federal Court brought to set aside the ruling of the Commission. (Lane v. Santa Rosa, 249 U. S. 110). If there were anything in the Lenroot Substitute which attempted to take away that right of recourse to the courts, it would be held unconstitutional.

It has been suggested that no decision against Pueblo claims should be valid without the consent of the Pueblos. It is unthinkable to stipulate the Indians' consent to the disposal of such lands as may not be legally theirs. Moreover, if the consent of one side were required, the consent of the other side would be equally necessary for fair action. As a matter of fact, in a judicial decision, the consent of either party is irrelevant. The court determines for both sides, regardless of contesting litigants or their wishes. However, by the actual terms of the Lenroot Substitute, "any party aggrieved by any final judgment or decree, shall have the right to review therof by appeal or writ of error or other process as in other cases."

\section{Need of a Commission}

The Commission is a necessary feature of the legislative act, since an equitable settlement of the disputed claims will entail actual first-hand knowledge of the ground, in connection with surveys made or ordered made, and an amount of first-hand investigation which could not be expected of the courts. The Commission makes its findings on the spot, in each respective pueblo, with all necessary witnesses, and without cost to either party. It is believed that $80 \%$. in number but not in area of the claims will thus be settled without cost to either party and without court proceedings. Considering: these facts. the inquiry conducted by the Commission may be expected to obtain for both elaimants a fuller measure of human and equitable iustice than conld be obtained through the courts.

Furthermore, the Commission is necessary to determine and report to Congress, as the courts could not efficiently do, the compensation 'which both the Indians and the settlers may be entitled to receive.

\section{Preserving the Pueblo Communities}

Another feature of proposed Pueblo legislation should be a practical method by which the Pueblo communities could be pre- 
served as such. In several Pueblos the settlers' claims are within the Pueblo plazas, and a possible sale or exchange of such nonIndian claims would be to the benefit of both races. Under Section 13 of the Lenroot Bill, it is provided that an unestinguished Pueblo claim within a settlement of valid non-Indian claims may be sold by the Secretary of the Interior with consent of the Pueblos' governing authorities. A section giving the Secretary of the Interior authority to purchase non-Indian claims inside the Pueblo settlements should also be included; and the Commission should be empowered to report upon these conditions where they exist, with an estimate of the cost to purchase non-Indian claims which are within Pueblo settlements or are so close thereto as to interfere with the Pueblo community life.

\section{Personnel of the Commission}

The Commission, as provided for in the Lenroot Substitute, includes the Secretary of the Interior, the Attorney General of the United States, and a third member appointed by the President. It has been suggested that the Pueblos have a specially elected representative on the Commission. In this event, a balancing right of special representation would obviously have to be accorded the settlers.. But this balance is officially maintained by the proposed personnel of the Commission: the Secretary of the Interior and the Attorney General, with a third member, the Presidential appointee; and the dissent of any one of these three leaves the Pueblo title unextinguished and subject to a final decision by the Court. Additional representation of the two sides is conceivable but would probably only complicate without advancing the work of the Commission..

\section{Conclusion}

Taking the Lenroot Substitute as a basis, with the added provisions indicated above and other possible amendments of a consistent nature, we have every reason to believe that a just and equitable solution of the complex Pueblo land problem will have been achieved.

(Signed) ALICE CORBIN HENDERSON, Chairman.

WITTER BYNNER,

E. DANA JOHNSON,

MARGARET MCKITTRICK,

Publicity Committee. 


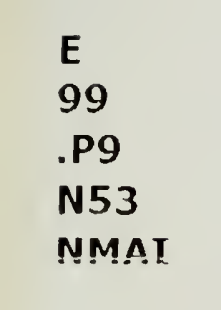


